ISSN : 2303-1514 | E-ISSN : 2598-5949

\title{
DISTANCE LEARNING DURING THE PANDEMIC AT SDN BENCONGAN VI
}

\author{
${ }^{*}$ Ramadhan $^{1}$, Sholeh Hidayat ${ }^{2}$, Indhira Asih Vivi Yandari ${ }^{3}$ \\ ${ }^{1,2,3}$ Universitas Sultan Ageng Tirtayasa, Tangerang, Indonesia \\ *2227170031@untirta.ac.id
}

\section{PEMBELAJARAN JARAK JAUH PADA MASA PANDEMI DI SDN BENCONGAN VI}

\begin{tabular}{|c|c|}
\hline ARTICLE HISTORY & ABSTRACT \\
\hline $\begin{array}{l}\text { Submitted: } \\
\text { 15 Juni } 2021 \\
15^{\text {th }} \text { June } 2021\end{array}$ & $\begin{array}{l}\text { Abstract: The aim of this research was to provide an overview of the implementationof online } \\
\text { distance learning during the pandemic at grade 4-C of elementary school. Learning before the } \\
\text { pandemic was certainly different from learning during the pandemic since the SARS-CoV-2 } \\
\text { virus was transmitted and caused Covid (Coronavirus Disease). Therefore, schools needed to } \\
\text { adjust the learning implementation, such as changing the interactions and learning methods. } \\
\text { The method used in this study was a qualitative descriptive method and the data collection } \\
\text { techniques used in this study were interviews, observation, and documentation. The results of } \\
\text { this study indicated that teachers carried out learning activities starting from preparing the } \\
\text { Lesson Plan (RPP), learning media (videos), and learning resources such as textbooks and } \\
\text { Student Worksheets (LKS). During the implementation of online distance learning, the teacher } \\
\text { carried out preliminary activities such as praying, asking students readiness, and } \\
\text { apperception, then, continuing to the core activities in which the teacher delivered the material } \\
\text { by using standard language, the learning resources, and doing question and answer with } \\
\text { students. Then, during the assessment, the teacher assessed students' spiritual and social } \\
\text { attitudes through learning via Google Meet, assessed students' knowledge using Google } \\
\text { Forms, and conducted skills assessments in the form of product assessments and practice } \\
\text { assessments. }\end{array}$ \\
\hline
\end{tabular}

Accepted:

22 Juli 2021

$22^{\text {th }}$ July 2021

Keywords: distance learning, pandemic, elementary school

Abstrak: Tujuan dari penelitian ini adalah untuk memberikan gambaran mengenai pelaksanaan pembelajaran jarak jauh daring pada masa pandemi di kelas 4-C sekolah dasar. Pembelajaran sebelum pandemi tentunya berbeda dengan pembelajaran sewaktu pandemi, hal ini dikarenakan virus SARS-CoV-2 yang dapat menular dan menyebabkan Covid (Coronavirus Disease), oleh karena itu sekolah perlu menyesuaikan pembelajaran yang dilakukan, seperti mengubah interaksi dan metode pembelajaran. Metode yang digunakan dalam penelitian ini adalah metode deskriptif kualitatif dan teknik pengumpulan data yang dilakukan pada penelitian ini adalah wawancara, observasi, dan dokumentasi. Hasil penelitian ini

Published:

25 Agustus 2021 menunjukkan bahwa guru melakukan kegiatan perencanaan pembelajaran seperti menyiapkan Rencana Pelaksanaan Pendidikan (RPP), media pembelajaran berupa video pembelajaran, menyiapkan sumber belajar berupa buku paket dan Lembar Kerja Siswa (LKS). Pada saat pelaksanaan pembelajaran jarak jauh daring, guru melakukan kegiatan pendahuluan seperti membaca doa, menanyakan kesiapan siswa, dan apersepsi, lalu pada kegiatan inti guru menyampaikan materi menggunakan bahasa yang baku, menggunakan sumber belajar berupa buku paket dan Lembar Kerja Siswa (LKS) dan melakukan tanya jawab dengan siswa. Pada penilaian pembelajaran, guru melakukan penilaian sikap spiritual dan sosial siswa melalui pembelajaran di Google Meet, penilaian pengetahuan siswa menggunakan Google Form, dan melakukan penilaian keterampilan berupa penilaian produk dan penilaian praktik.

Kata Kunci: pembelajaran jarak jauh, pandemi sekolah dasar

\section{CITATION}

Ramadhan, R., Hidayat, S., \& Yandari, I. A. V. (2021). Distance Learning during the Pandemic at SDN Bencongan VI. Jurnal Pendidikan Guru Sekolah Dasar, 10 (4), 749-765. DOI:http://dx.doi.org/10.33578/jpfkip.v10i4.8359. 


\section{PENDAHULUAN}

Pembelajaran yang awalnya dilakukan secara tatap muka, terpaksa harus diubah dikarnakan pandemi Covid-19. Tetapi jika pembelajaran tatap muka tidak segera dilakukan hal ini akan berdampak pada tumbuh kembang siswa seperti kesenjangan capaian belajar yang disebabkan gap akses dan kualitas pembelajaran, ketidakoptimalan pertumbuhan anak pada masa emas terutama pada jenjang PAUD, dan risiko learning loss. Menurut Organisation for Economic Cooperation and Development (OECD, 2020:6) learning loss adalah sebuah fenomena di mana ketika anak tidak sekolah, anak akan kehilangan keterampilan dan kompetensinya. Semkin lama hal ini terjadi, maka akan semakin besar dampak dari learning loss ini. Selain learning loss, dampak yang akan terjadi jika pembelajaran tatap muka tidak segera dilakukan maka adalah tekanan psikososial dan kekerasan dalam rumah tangga. Contohnya seperti anak stres karena kurangnya interaksi dengan guru, tekanan akibat sulitnya pembelajaran jarak jauh serta banyak siswa yang mengalami kekerasan rumah tangga tanpa terdeteksi.

Di lain sisi, penanganan Covid-19 di Indonesia jauh dari kata optimal. Hal ini dapat dilihat dari laporan Satgas Penanganan Covid19 pada 2020, positivity rate selama bulan Juni - November 2020 selalu di atas 10\%, di mana standar positivy rate menurut World Health Organization (WHO) adalah 5\%. Positivity rate adalah persentase kasus positif yang ditemukan pada sejumlah orang yang diperiksa. Laporan Satgas Penanganan Covid19 tersebut juga memaparkan bahwa jumlah kasus positif Covid-19 di Provinsi Banten mengalami kenaikan sebesar $45.7 \%$ pada minggu terakhir, dari 573 kasus menjadi 835 kasus. Selain itu, Kabupaten Tangerang juga merupakan daerah dengan risiko sedang/zona oranye dengan jumlah kasus tertinggi di Provinsi Banten, yaitu sebanyak 3.354 kasus.

Orang tua siswa tidak melihat peran sekolah ketika pembelajaran karena pembelajaran hanya dilakukan dengan guru menginstruksikan kepada siswa untuk mengerjakan soal atau tugas di buku paket/lembar kerja siswa melalui grup WhatsApp. Kegiatan pelaksanaan pembelajaran di masa pandemi yang monoton dan tidak memanfaatkan teknologi dengan optimal ini juga akan mengakibatkan siswa bosan dan jenuh ketika pembelajaran. Rendahnya mutu/kualitas interaksi pembelajaran jarak jauh ini juga sesuai dengan yang dikemukakan oleh Arsendy dkk. (2020:4). Melalui perluasan data dan komparasi kualitatif survei nasional diperoleh data sekitar 60\%-70\% guru di Indonesia berinteraksi secara langsung dengan siswa atau melalui orang tua menggunakan telepon seluler, aplikasi internet, atau kunjungan rumah dan aplikasi ponsel yang sering digunakan adalah WhatsApp. Kemudian sekitar $10 \%$ guru hanya memberikan tugas/pekerjaan rumah ke siswa tanpa berinteraksi/memberikan balikkan ke siswa. Sementaranya sisanya, guru tidak melakukan interaksi dengan siswa sama sekali. Biasanya siswa belajar secara mandiri melalui siaran televisi/radio, bahkan ada beberapa siswa yang tidak belajar sama sekali.

Tapi, rendahnya mutu/kualitas interaksi pembelajaran jarak jauh ini berbeda ketika peneliti melakukan praktik pembelajaran bersama wali kelas di kelas 4-C SDN Bencongan VI yang bernama Pak Sukirman. Sebelum melakukan praktik pembelajaran, peneliti melakukan wawancara dan pengamatan terkait pelaksanaan kegiatan pembelajaran sekolah ini, khususnya di kelas 4-C. Wawancara dan pengamatan tersebut dilakukan pada hari Rabu, 4 November 2020. Setelah melakukan wawancara dan penelitian, peneliti mendapatkan informasi bahwa Pak Sukirman melakukan pembelajaran jarak jauh luring menggunakan WhatsApp dengan menginstruksikan siswa untuk mengerjakan soal atau tugas melalui grup WhatsApp. Selain itu, Pak Sukirman juga melakukan pembelajaran jarak jauh daring dengan 
melakukan videokonferensi melalui Google Meet setiap hari Selasa setiap minggunya. Hal ini yang menjadi perbedaan dari sekolah dasar negeri lainnya dan sekaligus dapat membuat pembelajaran lebih menarik dan tidak membosankan, orang tua juga dapat melihat peran guru dalam pembelajaran selama pandemi, dan dapat menjadi variasi pelaksanaan pembelajaran pada masa pandemi bagi guru, kepala sekolah dsb.

Berdasarkan paparan tersebut, maka dapat dikatakan bahwa pandemi Covid-19 membuat pembelajaran menjadi tak menentu. Pembelajaran yang semula dilakukan secara tatap muka berubah menjadi pembelajaran jarak jauh. Pembelajaran jarak jauh juga dapat dilakukan baik secara daring maupun luring.

\section{METODE PENELITIAN}

Metode penelitian yang digunakan pada penelitian ini adalah deskriptif. Deskriptif adalah data yang dikumpulkan berupa deskripsi (kata-kata, gambar, dan bukan angkaangka). Hal ini dikarenakan penerapan metode kualitatif. Selain itu, semua data yang dikumpulkan memiliki kemungkinan untuk menjadi kunci terhadap apa yang sudah diteliti.

Pendekatan penelitian yang digunakan pada penelitian ini adalah pendekatan kualitatif. Penelitian kualitatif adalah penelitian yang bertujuan untuk memahami fakta tentang apa yang dialami oleh subjek penelitian (contohnya seperti perilaku, tanggapan, dorongan, tindakan, dll.) secara menyeluruh dan menggambarkannya dalam bentuk kata-kata dan bahasa pada suatu konteks khusus yang alamiah dan dengan memanfaatkan berbagai metode saintifik (ilmiah). Pada penelitian kualitatif juga peneliti menjadi instrumen kunci. Teknik pengumpulan data dilakukan melalui triangulasi. Triangulasi yang digunakan pada penelitian kali ini adalah triangulasi teknik pengumpulan data di mana data dikumpulkan mengunakan teknik wawancara, observasi, dan dokumentasi.

Teknik pengumpulan data yang digunakan pada penelitian ini adalah wawancara, observasi, dan dokumentasi. Wawancara dilakukan pada hari Kamis, 1 April 2021 di SDN Bencongan VI secara tatap muka dengan tetap mengikuti protokol kesehatan bersama narasumber, Pak Sukirman. Wawancara dilakukan untuk mengetahui bagaimana perencanaan dan penilaian pembelajaran jarak jauh yang dilakukan guru. Observasi juga dilakukan sebanyak empat kali menggunakan rekaman pembelajaran Google Meet pada bulan Januari- Februari 2021. Observasi dilakukan untuk mengetahui bagaimana pelaksanaan pembelajaran jarak jauh di kelas 4-C SDN Bencongan VI.

Analisis data yang digunakan pada penelitian ini adalah analisis data dari Miles dan Huberman. Analisis data kualitatif ialah analisis yang urutan pelaksanaan yang keberlangsungannya terjadi secara terusmenerus bersamaan dengan dilakukannya kegiatan penelitian (pengumpulan data). Berikut ini merupakan contoh model analisis data model Miles dan Huberman.

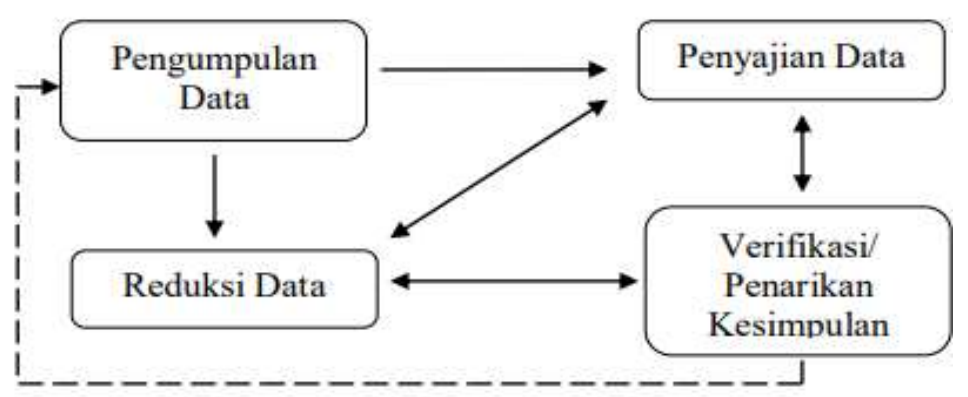

Gambar 1. Analisis Data Model Miles dan Huberman 


\section{a. Pengumpulan Data}

Dalam penelitian ini, pengumpulan data dilakukan dengan wawancara, observasi, dan dokumentasi atau gabungan ketiganya (triangulasi). Pengumpulan dilakukan terusmenerus sehingga data yang diperoleh akan banyak.

\section{b. Reduksi Data}

Dari asal katanya, reduksi artinya pengurangan/pemotongan. Data yang diperoleh dari lapangan dituangkan ke dalam bentuk laporan. Data dan laporan selanjutnya direduksi dengan memilih data (pokok) yang peneliti anggap penting. Proses ini dapat dilakukan dengan memilah dan memilih hal yang pokok (penting) untuk kemudian dicari tema dan polanya. Secara singkat, reduksi data adalah kegiatan merangkum data (pokok) yang dianggap penting, kemudian dicari tema/polanya. Reduksi data dilakukan secara terus-menerus selama proses penelitian.

\section{c. Penyajian Data}

Penyajian data dalam penelitian kualitatif dapat dilakukan dalam bentuk uraian singkat, bagan, dan lain sebagainya. Dalam penelitian kualitatif, bentuk (penyajian data) yang paling banyak digunakan dalam penelitian kualitatif ialah teks dalam bentuk naratif. Penelitian ini menggunakan penyajian data berbentuk naratif (cerita/deskripsi). Melalui proses ini, maka data akan menjadi teratur dan tersusun ke dalam bentuk tertentu agar dapat lebih mudah dipahami. Penyajian data juga bertujuan agar peneliti dapat lebih mudah untuk melihat fenomena secara holistik maupun parsial.

\section{d. Penarikan Kesimpulan/Verifikasi}

Penarikan kesimpulan dalam penelitian kualitatif adalah penelitian dapat menjawab rumusan masalah yang telah dirumuskan sejak awal, tetapi bisa juga tidak dapat menjawab rumusan masalah. Hal ini dikarenakan masalah dan rumusan masalah dalam penelitian kualitatif hanya bersifat sementara dan akan terus berkembang ketika peneliti sudah berada di lapangan. Proses penarikan kesimpulan juga tidak dilakukan oleh peneliti sendiri, melainkan juga dibantu oleh pelaku budaya sebagai subjek penelitian, para anggota tim penelitian, juga para ahli terkait.

Dalam menguji keabsahan data penelitian kualitataif dapat dilakukan dengan uji credibility (validitas internal), transferability (validitas eksternal), dependability (reliabilitas), dan confirmability (objektivitas).

\section{Uji Credibility}

Uji credibility data atau kepercayaan terhadap data hasil dari penelitian kualitatif antara lain dapat dilakukan dengan cara:

\section{a. Perpanjangan Pengamatan}

Dengan melakukan perpanjangangan pengamatan berarti peneliti melakukan wawancara dan pengamatan lagi dengan sumber data, baik yang pernah ditemui atau yang baru. Dengan melakukan pernpanjangan pengamatan, maka hubungan antara peneliti dan sumber data akan menjadi lebih dekat sehingga sumber data akan lebih terbuka ke peneliti. Perpanjangan pengamatan dilakukan dengan mengecek apakah data yang didapatkan itu benar atau tidak, berubah atau tidak.

\section{b. Meningkatkan Ketekunan}

Meningkatkan ketekunan berarti melakukan pengamatan secara lebih saksama, teliti dan berkelanjutan. Dengan meningkatkan ketekunan, maka peneliti dapat menentukan apakah data yang diambil itu salah atau tidak. Peneliti dapat meningkatkan ketekunan dengan membaca berbagai referensi buku, hasil penelitian atau dolumentasi yang relevan dengan temuan yang diteliti.

\section{c.Triangulasi}

Triangulasi dapat dikatakan sebagai pengecekan data dari berbagai sumber dengan berbagai macam cara dan waktu. Ada triangulasi sumber (mengecek data yang sudah diperoleh melalui beberapa sumber), triangulasi teknik pengumpulan data (mengecek data kepada sumber yang sama dengan teknik yang berbeda), dan triangulasi waktu (pengecekan data dengan waktu yang 
berbeda). Triangulasi yang digunakan pada penelitian ini adalah triangulasi teknik pengumpulan data dan triangulasi waktu observasi

\section{d. Menggunakan Bahan Referensi}

Menggunakan bahan referensi dilakukan untuk membuktikan data yang sebelumnya sudah ditemukan. Dalam laporan penelitian, data yang ditemukan sebaiknya didukung dengan bukti seperti rekaman wawancara, foto, dan lain sebagainya.

\section{e. Diskusi Teman Sejawat}

Melalui diskusi dengan teman sejawat, maka peneliti akan mendapatkan pendapat yang berbeda. dari diskusi ini juga dapat menghasilkan masukan, kritik, serta tanggapan bagi peneliti

\section{Uji Transferability}

Uji transferability ini berkaitan proses yang mencoba menjawab pertanyaan sejauh mana hasil dari penelitian dapat diterapkan/digunakan ke konteks/situasi yang berbeda. Bagi peneliti, nilai transfer ini sangat bergantung pada pembaca. Sehingga, ketika hasil penelitian ini dapat digunakan dalam konteks/situasi yang berbeda, maka penelitian ini dapat dikatakan memiliki nilai transfer. Jika pembaca memperoleh suatu gambaran jelas dari hasil penelitian yang dibacanya, maka hasil penelitian tersebut dapat diberlakukan transferability atau hasil penelitiannya dapat dikatakan sudah memenuhi standar transferability.

\section{Uji Dependability}

Uji dependability (dapat dipercaya) dalam penelitian kualitatif dilakukan dengan cara melakukan audit (pemeriksaan) terhadap keseluruhan proses penelitian. Jika peneliti tidak melakukan penelitian, sementara datanya ada, maka penelitian dapat dikatakan tidak reliabel atau dependable (tidak dapat dipertangungjawabkan).

\section{Uji Confirmability}

Penelitian dapat dikatakan objektif apabila hasil penelitian diakui/disepakati (dikonfirmasi) oleh banyak pihak. Uji confirmability hampir sama dengan uji dependability sehingga pengujiannya dapat dilakukan bersamaan. Menguji confirmability artinya menguji hasil penelitian yang dikaitkan dengan proses ketika dilakukan. Artinya, apabila hasil penelitian merupakan fungsi dari proses penelitian, maka penelitian tersebut sudah memenuhi standar confirmability.

\section{HASIL DAN PEMBAHASAN}

Setelah peneliti melakukan penelitian meliputi kegiatan wawancara, observasi, dan dokumentasi. Setelah itu, peneliti menjabarkannya ke dalam hasil penelitian. Pada bagian ini peneliti akan membahas hasil penelitian yang sudah diperoleh melalui observasi, wawancara, dan dokumentasi. Pembahasan yang akan peneliti lakukan yaitu pembahasan dari hasil penelitian sebagai berikut.

\section{Perencanaan Pembelajaran pada Masa Pandemi di Kelas 4-C SDN Bencongan VI}

Sebelum melakukan sesuatu, sebaiknya direncanakan dengan matang agar pekerjaan yang dilakukan dapat berjalan dengan baik. Hal ini juga termasuk ketika kita mau melakukan pembelajaran. Sebelum melakukan pembelajaran, guru harus merencanakan pembelajaran terlebih dahulu agar pembelajaran berjalan dengan baik. Dari sini peneliti ingin mengetahui bagaimana perencanaan pembelajaran pada masa pandemi di sekolah dasar.

Peneliti melakukan wawancara untuk mendapatkan informasi mengenai perencanaan pembelajaran pada masa pandemi. Wawancara dilakukan untuk menggali informasi guru sebagai pengajar di sekolah. Berikut ini adalah hasil wawancara yang dilakukan oleh peneliti dengan guru mengenai perencanaan pembelajaran pada masa pandemi di kelas 4-C SDN Bencongan VI.

\section{a. Menyusun RPP}

Dalam melakukan pembelajaran pada masa pandemi, guru menyusun RPP. RPP tersebut disusun di awal tahun pembelajaran secara kolektif dan digunakan untuk setahun. Beliau mendapatkan RPP tersebut dengan 
menyusunnya sendiri dan mengunduhnya dari internet. Beliau juga memodifikasi RPP yang diperoleh dari internet agar RPP tersebut sesuai dengan pembelajaran jarak jauh daring, misalnya tugas (keterampilan) yang biasanya dapat dilakukan secara langsung, diubah menjadi tugas video. Kegiatan pembelajaran yang biasanya dilakukan secara langsung di kelas, tinggal disampaikan melalui Google Meet, jadi tidak perlu mengubah RPP. Terakhir, beliau juga menambahkan kalau pembelajaran jarak jauh daring, yang disampaikan hanya materi saja.

\section{b. Menyiapkan media pembelajaran dan sumber ajar}

Salah satu media pembelajaran yang digunakan oleh guru adalah video. Guru mendapatkan video pembelajaran tersebut dengan mengunduhnya dari Youtube. Video yang biasanya digunakan dalam pembelajaran adalah video materi matematika, video seni budaya dan kerajinan/prakarya, dll. Selain itu, guru juga menggunakan sumber belajar berupa buku tematik dan buku Lembar Kerja Siswa (LKS). Guru juga menggunakan buku LKS untuk tugas/latihan soal siswa, sedangkan buku tematik digunakan sebagai referensi, pelengkap, atau pembahasan materi yang bersifat mendalam. Buku tematik diberikan/dipinjamkan ke siswa, sedangkan buku LKS harus dibeli seharga Rp10.000/buku.

\section{c. Menyiapkan penilaian}

Penilaian yang biasanya disiapkan oleh guru berupa soal pilihan ganda dan esai. Bentuk soal pilihan ganda dan esai dipilih guru karena lebih efektif, pasalnya soal pilihan ganda dapat menggunakan Google Form. Jadi nilai dari jawaban soal pilihan ganda tersebut otomatis langsung muncul di Google Form, sehingga menjadi lebih efektif. Soal tersebut terkadang dibuat sendiri oleh guru atau beliau mengambil soal dari buku LKS.

\section{d. Menyiapkan tindak lanjut pembelajaran}

Guru biasanya memberikan tugas di luar jam pembelajaran. Tugas yang bisanya diberikan adalah tugas tematik, matematika,
PJOK, SBK/prakarya. Guru menggunakan Google Form untuk tugas soal pilihan ganda dan untuk tugas prakarya/SBK biasanya dikumpulkan. Durasi yang berikan untuk menyelesaikan tugas bergantung berbanding lurus dengan tingak kesukaran tugas tersebut, semakin sukar maka semakin lama, begitu juga sebaliknya. Biasanya durasi penyelesaian tugas yang diberikan guru berkisar dari satu hari sampai satu minggu.

Berdasarkan hasil wawancara, maka perencanaan pembelajaran di masa pandemi yang dilakukan oleh guru adalah menyusun rencana pelaksanaan pembelajaran di awal tahun pembelajaran secara mandiri dan dari internet. Tetapi ketika peneliti melakukan pengamatan, peneliti tidak melihat kesamaan antara kegiatan pembelajaran yang dilakukan dengan RPP yang peneliti dapatkan. Hal ini juga tidak sejalan dengan hasil dokumentasi, RPP yang disiapkan tersebut bersumber dari internet dan hanya dimodifikasi bagian nama kepala sekolah, nama guru, dan nomor induk pegawai kepala sekolah. Peneliti mengetahuinya ketika peneliti melihat pada salah satu bagian belakang kertas RPP terdapat pranala (link) "katulis.com" dan Google Docs, setelah peneliti mengunjungi laman web tersebut terdapat dokumen RPP. Hal ini juga tidak sesuai dengan yang termaktub dalam Lampiran Permendikbud Nomor 22 Tahun 2016 tentang Standar Proses Pendidikan Dasar dan Menengah halaman 6 yang berbunyi, "Setiap pendidik pada satuan pendidikan berkewajiban menyusun RPP secara lengkap dan sistematis agar pembelajaran berlangsung secara interaktif, inspiratif, menyenangkan, menantang, efisien, memotivasi peserta didik untuk berpartisipasi aktif, serta memberikan ruang yang cukup bagi prakarsa, kreativitas, dan kemandirian sesuai dengan bakat, minat, dan perkembangan fisik serta psikologis peserta didik."

Berbeda dengan RPP, berdasarkan hasil wawancara mengenai perencanaan pembelajaran, guru juga menyiapkan media pembelajaran berupa video. Video yang 
disiapkan oleh guru diperoleh dengan mengunduhnya dari internet. Hal ini juga sesuai dengan hasil dokumentasi, guru terlihat mengirim video pembelajaran yang berisi materi pembelajaran ke grup WhatsApp kelas. Video pembelajaran biasanya digunakan ketika guru melakukan pembelajaran jarak jauh daring menggunakan WhatsApp. Hal ini sesuai dengan yang terdapat di dalam Lampiran Permendikbud Nomor 22 Tahun 2016 tentang Standar Proses Pendidikan Dasar dan Menengah pada halaman 7 yang berbunyi, "Media pembelajaran, berupa alat bantu proses pembelajaran untuk menyampaikan materi pelajaran."

Selain menyiapkan media pembelajaran berupa video, berdasarkan hasil wawancara mengenai perencanaan pembelajaran, guru juga menyiapkan sumber belajar berupa buku tematik dan buku lembar kerja siswa (LKS). Buku tematik dipinjamkan oleh sekolah sedangkan buku LKS harus dibeli oleh siswa. Hal ini sejalan dengan hasil dokumentasi di grup WhatsApp kelas, guru menyiapkan buku paket dan buku LKS di awal semester. Selain itu, guru juga menggunakan buku tematik atau buku LKS untuk pembelajaran atau penugasan. Hal ini sesuai dengan yang termuat dalam Lampiran Permendikbud Nomor 22 Tahun 2016 tentang Standar Proses Pendidikan Dasar dan Menengah pada halaman 7 yang berbunyi, "Sumber belajar, dapat berupa buku, media cetak dan elektronik, alam sekitar, atau sumber belajar lain yang relevan;"

Setelah pembelajaran, biasanya guru akan melakukan penilaian ke siswa. Sebelum melakukan penilaian, guru harus menyiapkan penilaian. Berdasarkan hasil wawancara, guru menyiapkan penilaian pembelajaran. Penilaian yang disiapkan berupa soal pilihan ganda. Soal tersebut diperoleh dengan membuat sendiri atau mengambil soal dari buku LKS. Guru membuat dan siswa mengisi jawaban soal tersebut di Google Form.

Sesuai dengan hasil dokumentasi, guru memberikan pranala Google Form di grup
WhatsApp kelas untuk melakukan penilaian. Hal ini sesuai dengan yang tercantum dalam Lampiran Permendikbud Nomor 22 Tahun 2016 tentang Standar Proses Pendidikan Dasar dan Menengah pada halaman 5 yang berbunyi, "Penilaian, merupakan proses pengumpulan dan pengolahan informasi untuk menentukan pencapaian hasil belajar peserta didik.'

Sebelum menutup pembelajaran biasanya guru memberikan tindak lanjut pembelajaran. Sebelum memberikan tindak lanjut pembelajaran, guru harus menyiapkan tindak lanjut tersebut. Berdasarkan hasil wawancara, guru memberikan tindak lanjut berupa soal di Google Form dan tugas prakarya (seni budaya dan prakarya) yang hasilnya langsung dikumpulkan atau diberikan durasi pengerjaan soal/tugas yang bervariasi tergantung tingkat kesukarannya, mulai dari satu hari sampai satu minggu. Hal ini sama dengan hasil dokumentasi, setelah pembelajaran melalui Google Meet, guru menginstruksikan siswa untuk mengerjakan soal di buku LKS, tugas praktik dan produk melalui grup WhatsApp kelas. Hal ini sesuai dengan Lampiran Permendikbud Nomor 22 Tahun 2016 tentang Standar Proses Pendidikan Dasar dan Menengah pada halaman 12 yang berbunyi, "Melakukan kegiatan tindak lanjut dalam bentuk pemberian tugas, baik tugas individual maupun kelompok."

\section{Pelaksanaan Pembelajaran pada Masa Pandemi di Kelas 4-C SDN Bencongan VI}

Setelah merencanakan pembelajaran, langkah selanjutnya adalah pelaksanan pembelajaran. Pelaksanaan pembelajaran jarak jauh daring yang dilakukan guru umumnya pembelajaran dibagi menjadi 3 tahap kegiatan, ada kegiatan pendahuluan, inti, dan penutup. Pelaksanaan pembelajaran yang awalnya berlangsung tatap muka, pada masa pandemi seperti sekarang ini pembelajaran menjadi pembelajaran jarak jauh daring. Dikarenakan pembelajaran dilakukan secara jarak jauh daring, maka peneliti melakukan pengamatan melalui hasil rekaman pembelajaran Google 
Meet, selain itu, peneliti juga merekam pembelajaran yang dilakukan guru.

Peneliti melakukan pengamatan untuk mendapatkan informasi mengenai pelaksanaan pembelajaran di masa pandemi. Pengamatan dilakukan untuk mengamati guru sebagai pengajar melalui hasil rekaman pembelajaran tematik menggunakan Google Meet pada bulan Januari-Februari 2021. Berikut ini adalah hasil pengamatan yang dilakukan oleh peneliti kepada guru saat melaksanaan pembelajaran jarak jauh daring pada masa pandemi di kelas 4-C SDN Bencongan VI.

a. Melaksanakan Kegiatan Pendahuluan

1) Guru mengucapkan salam sebelum memulai pembelajaran

Peneliti melakukan kegiatan pengamatan mengenai kegiatan pendahuluan yang berkaitan dengan guru mengucapkan salam sebelum memulai pembelajaran. Berdasarkan hasil pengamatan pertama pada pembelajaran hari Selasa tanggal 12 Januari 2021, pengamatan kedua pada pembelajaran hari Selasa tanggal 19 Januari 2021 , pengamatan ketiga pada pembelajaran hari Selasa tanggal 26 Januari 2021 , pengamatan keempat pada pembelajaran hari Selasa tanggal 2 Februari 2021 peneliti tidak melihat guru mengucapkan salam sebelum memulai pembelajaran. Dari sini peneliti menyimpulkan bahwa ketika melakukan kegiatan pendahuluan pembelajaran menggunakan Google Meet, guru tidak mengucapkan salam sebelum memulai pembelajaran.

\section{2) Guru menanyakan kesiapan siswa}

Peneliti melakukan pengamatan mengenai kegiatan pendahuluan yaitu guru menanyakan kesiapan siswa. Pada pengamatan pertama pada pembelajaran hari Selasa tanggal 12 Januari 2021 peneliti melihat guru menanyakan ke siswa apakah mereka sudah membuka buku halaman 19 atau belum. Pengamatan kedua pada pembelajaran hari Selasa tanggal 19 Januari 2021, peneliti melihat guru menanyakan ke siswa apakah mereka sudah menyiapkan buku paket atau belum. Pada pengamatan ketiga pada pembelajaran hari Selasa tanggal 26 Januari 2021, peneliti melihat guru menanyakan apakah siswa sudah membuka buku pada halaman 93 atau belum. Pada pengamatan keempat, pada pembelajaran hari Selasa tanggal 2 Februari 2021, peneliti melihat guru menanyakan ke siswa apakah mereka sudah menyiapkan buku atau belum. Dari sini peneliti menyimpulkan bahwa ketika melakukan kegiatan pendahuluan pembelajaran menggunakan Google Meet, guru menanyakan kesiapan siswa.

\section{3) Guru membaca doa sebelum memulai pembelajaran}

Peneliti melakukan pengataman mengenai kegiatan pendahuluan yaitu guru membaca doa sebelum memulai pembelajaran. Pada pengamatan pertama pada pembelajaran hari Selasa tanggal 12 Januari 2021 peneliti tidak melihat guru membaca doa sebelum memulai pembelajaran. Pada penelitian kedua pada pembelajaran hari Selasa tanggal 19 Januari 2021 peneliti melihat guru membaca doa sebelum belajar bersama siswa. Pada pengamatan ketiga yang dilakukan pada pembelajaran hari Selasa tanggal 26 Januari 2021, peneliti melihat guru membaca doa sebelum belajar bersama siswa. Pada pengamatan keempat yang dilakukan pada pembelajaran hari Selasa tanggal 2 Februari 2021 peneliti melihat guru membaca doa sebelum belajar bersama siswa. Dari sini peneliti menyimpulkan bahwa ketika melakukan kegiatan pendahuluan pembelajaran menggunakan Google Meet, guru membaca doa sebelum memulai pembelajaran.

\section{4) Guru mengecek kehadiran siswa}

Peneliti melakukan kegiatan pengamatan mengenai kegiatan pendahuluan yang berkaitan dengan guru mengecek kehadiran siswa. Berdasarkan hasil pengamatan pertama pada pembelajaran hari Selasa tanggal 12 Januari 2021, pengamatan kedua pada pembelajaran hari Selasa tanggal 19 Januari 2021, pengamatan ketiga pada pembelajaran hari Selasa tanggal 26 Januari 
2021, dan pengamatan keempat pada pembelajaran hari Selasa tanggal 2 Februari 2021 peneliti tidak melihat guru mengecek kehadiran siswa. Dari sini peneliti menyimpulkan bahwa ketika melakukan kegiatan pendahuluan pembelajaran menggunakan Google Meet, guru tidak mengecek kehadiran siswa.

\section{5) Guru melakukan apersepsi}

Peneliti melakukan kegiatan pengamatan mengenai kegiatan pendahuluan yang berkaitan dengan guru melakukan apersepsi. Berdasarkan hasil pengamatan pertama pada pembelajaran hari Selasa tanggal 12 Januari 2021, peneliti melihat guru melakukan apersepsi dengan menghubungkan pengalaman siswa dengan materi yang akan dipelajari dengan menanyakan ke siswa, "Apakah kalian pernah melihat kupu-kupu?" setelah itu dilanjutkan dengan membahas tentang daur hidup (metamorfosis) kupu-kupu. Pada pengamatan kedua di pembelajaran hari Selasa tanggal 19 Januari 2021 peneliti melihat guru melakukan apersepsi dengan menyinggung pembelajaran minggu kemarin, yaitu materi tentang puisi dan tugas membuat puisi bertema cita-citaku, kemudian menjelaskan bahwa cita-cita adalah harapan dan menanyakan kepada siswa apakah kemarin mereka sudah bisa membuat puisi atau belum? Terakhir, memberikan nasihat kepada siswa untuk berlatih membaca puisi dan melanjutkan materi mengenai daur hidup katak. Pada pengamatan ketiga pada pembelajaran hari Selasa tanggal 26 Januari 2021 peneliti melihat guru melakukan apersepsi dengan menghubungkan pengalaman siswa dengan materi yang akan dipelajari dengan menanyakan "Apakah kalian pernah ke Candi Borobudur?" dan melanjutkan membahas tentang Candi Borobudur. Pada pengamatan keempat pada pembelajaran hari Selasa tanggal 2 Februari 2021 peneliti melihat guru melakukan apersepsi dengan menanyakan, "Apakah kalian sudah membuat puisi atau belum?" dan melanjutkan dengan membahas unsur puisi (unsur intrinsik dan ekstrinsik), kemudian mengulas secara singkat materi yang sudah dipelajari, yaitu materi tentang daur hidup makhluk hidup seperti kupu-kupu, ikan, dan ayam. Setelah itu, melanjutkan pembelajaran dengan menjawab soal di buku LKS bersama siswa. Dari sini peneliti menyimpulkan bahwa ketika melakukan kegiatan pendahuluan pembelajaran menggunakan Google Meet, guru melakukan apersepsi.

\section{6) Guru memberikan motivasi ke siswa}

Peneliti melakukan kegiatan pengamatan mengenai kegiatan pendahuluan yang berkaitan dengan guru memberikan motivasi ke siswa. Berdasarkan hasil pengamatan pertama pada pembelajaran hari Selasa tanggal 12 Januari 2021 peneliti tidak melihat guru memberikan motivasi ke siswa. Pada pengamatan kedua yang dilakukan pada pembelajaran hari Selasa tanggal 19 Januari 2021 peneliti melihat guru memberikan nasihat kepada siswa untuk berlatih membaca puisi. Pada pengamatan ketiga yang dilakukan pada pembelajaran hari Selasa tanggal 26 Januari 2021 dan pengamatan keempat yang dilakukan pada pembelajaran hari Selasa tanggal 2 Februari 2021 peneliti tidak melihat guru memberikan motivasi ke siswa. Dari sini peneliti menyimpulkan bahwa ketika melakukan kegiatan pendahuluan pembelajaran menggunakan Google Meet, guru tidak memberikan motivasi ke siswa.

\section{b. Melaksanakan Kegiatan Inti}

\section{1)Guru menyampaikan materi} pembelajaran

Peneliti melakukan kegiatan pengamatan mengenai kegiatan inti yang berkaitan dengan guru menyampaikan materi pembelajaran. Berdasarkan hasil pengamatan pertama pada pembelajaran hari Selasa tanggal 12 Januari 2021 peneliti melihat guru menyampaikan materi tentang metamorfosis kupu-kupu dan belalang, peternakan, pertanian, peta konsep, sumber daya alam yang dapat diperbaharui dan tidak dapat diperbaharui/ Pada pengamatan kedua pada pembelajaran hari Selasa tanggal 19 Januari 
2021 peneliti melihat guru menyampaikan materi tentang daur hidup katak, kecoak, capung, nyamuk, cara mencegah agar nyamuk tidak berkembang biak di rumah, manfaat makhluk hidup di sekitar kita, dan Patih Gajah Mada. Pada pengamatan ketiga pada pembelajaran hari Selasa tanggal 26 Januari 2021 peneliti melihat guru membahas materi tentang candi Borobudur, waduk Jatiluhur, jembatan Suramadu, arsitek, rumah adat Kampung Naga, Jawa Barat, manfaat sumber daya alam di sekitar kita, masakan nusantara, polisi, tentara nasional Indonesia, "Si Pendekar Kali Pesanggrahan", "Aku, Sarjana Pemulung", dan "Sang Arsitek". Pada pengamatan keempat pada pembelajaran hari Selasa tanggal 2 Februari 2021 peneliti melihat guru menyampaikan materi tentang unsur puisi (intrinsik dan ekstrinsik) daur hidup makhluk hidup (kupu-kupu, ikan, dan ayam). Dari sini peneliti menyimpulkan bahwa ketika melakukan kegiatan inti pembelajaran menggunakan Google Meet, guru menyampaikan materi pembelajaran.

\section{2) Guru menggunakan bahasa baku}

Peneliti melakukan kegiatan pengamatan mengenai kegiatan inti yang berkaitan dengan guru menggunakan bahasa baku. Berdasarkan hasil pengamatan pertama pada pembelajaran hari Selasa tanggal 12 Januari 2021, pengamatan kedua pada pembelajaran hari Selasa tanggal 19 Januari 2021, pengamatan ketiga pada pembelajaran hari Selasa tanggal 26 Januari 2021, dan pengamatan keempat pada pembelajaran hari Selasa tanggal 2 Februari 2021 guru selalu menggunakan bahasa yang baku. Dari sini peneliti menyimpulkan bahwa ketika melakukan kegiatan inti pembelajaran menggunakan Google Meet, guru menggunakan bahasa baku.

\section{3) Guru menggunakan sumber belajar}

Peneliti melakukan kegiatan pengamatan mengenai kegiatan inti yang berkaitan dengan guru menggunakan sumber belajar. Berdasarkan hasil pengamatan pertama pada pembelajaran hari Selasa tanggal 12
Januari 2021, pengamatan kedua pada pembelajaran hari Selasa tanggal 19 Januari 2021, pengamatan ketiga pada pembelajaran hari Selasa tanggal 26 Januari 2021 peneliti melihat guru menggunakan sumber belajar berupa buku teks tematik tema 6 dan pengamatan keempat pada pembelajaran hari Selasa tanggal 2 Februari 2021 peneliti melihat guru menggunakan sumber belajar berupa buku LKS. Dari sini peneliti menyimpulkan bahwa ketika melakukan kegiatan inti pembelajaran menggunakan Google Meet, guru menggunakan sumber belajar.

\section{4) Guru melakukan tanya jawab bersama} siswa

Peneliti melakukan kegiatan pengamatan mengenai kegiatan inti yang berkaitan dengan guru melakukan tanya jawab bersama siswa. berdasrkan hasil pengamatan pertama pada pembelajaran hari Selasa tanggal 12 Januari 2021, hari Selasa tanggal 19 Januari 2021, hari Selasa tanggal 26 Januari 2021, dan 2 Februari 2021 peneliti melihat guru sering melakukan tanya jawab terutama pertanyaan yang berkaitan dengan materi dan kehidupan/pengalaman siswa dan memberikan kesempatan siswa untuk mengakhiri kata/kalimat agar terjadi interaksi dua arah seperti melakukan tanya jawab dengan siswa mengenai materi yang aiarkan atau menjawab soal bersama siswa. Contohnya pada pengamatan pertama yang dilakukan pada pembelajaran hari Selasa tanggal 12 Januari 2021 terlihat guru dan siswa melakukan tanya jawab tentang sumber daya alam yang dapat diperharui dan tidak dapat diperbaharui. Pada pengamatan kedua yang dilakukan pada pembelajaran hari Selasa tanggal 19 Januari 2021 terlihat beliau melakukan tanya jawab dengan siswa mengenai apa saja ikan yang termasuk jenis ikan air tawar

Pada pengamatan ketiga yang dilakukan pada pembelajaran hari Selasa tanggal 26 Januari peneliti melihat guru melakukan tanya jawab dengan siswa tentang arsitek dan bangunan bersejarah/infrastruktur dengan pertanyaan seperti apa sebutan orang 
yang merancang bangunan? Siapa artsitek (yang merancang) Candi Borobudur? Dan ada di mana Jembatan Suramadu? Lalu siswa menjawabnya. Pada pengamatan keempat yang dilakukan pada pembelajaran hari Selasa tanggal 2 Februari 2021, peneliti melihat guru melakukan tanya jawab dengan siswa sambil mengisi soal yang ada di buku LKS bersama siswa. Pertanyaan yang dilontarkan adalah soal yang ada di buku LKS, seperti pertanyaan tentang sumber daya alam, pekerjaan/profesi, cita-cita, dan puisi. Dari sini peneliti menyimpulkan bahwa ketika melakukan kegiatan inti pembelajaran menggunakan Google Meet, guru melakukan tanya jawab bersama siswa.

\section{c. Melakukan Kegiatan Penutup}

\section{1) Guru menyimpulkan pembelajaran}

Peneliti melakukan kegiatan

pengamatan mengenai kegiatan penutup yang berkaitan dengan guru menyimpulkan pembelajaran. Berdasarkan hasil pengamatan pertama pada pembelajaran hari Selasa tanggal 12 Januari 2021, pengamatan kedua pada pembelajaran hari Selasa tanggal 19 Januari 2021, pengamatan ketiga pada pembelajaran hari Selasa tanggal 26 Januari 2021, dan pengamatan keempat pada pembelajaran hari Selasa tanggal 2 Februari 2021 peneliti tidak melihat guru menyimpulkan pembelajaran. Dari sini peneliti menyimpulkan bahwa ketika melakukan kegiatan penutup pembelajaran menggunakan Google Meet, guru tidak menyimpulkan pembelajaran.

\section{2) Guru memberikan tugas lanjutan di luar pembelajaran}

Peneliti melakukan kegiatan pengamatan mengenai kegiatan penutup yang berkaitan dengan guru memberikan tugas lanjutan di luar pembelajaran. Pada pengamatan yang dilakukan pada pembelajaran hari Selasa tanggal 12 Januari 2021 peneliti melihat guru memberikan tugas kepada siswa untuk menggambar salah satu peternakan hewan yang ada di buku tematik kelas 4 tema 6 halaman 26 di kertas karton yang telah dipotong menjadi 4 bagian dan diwarnai. Pada pengamatan kedua yang dilakukan pada pembelajaran hari Selasa tanggal 19 Januari 2021 peneliti melihat guru memberikan tugas kepada siswa untuk membaca puisi yang ada di buku tematik kelas 4 tema 6 halaman 86 yang berjudul "Maha Patih Gajah Mada" dengan indah (suara dan intonasi yang bagus) kemudian direkam dan dikumpulkan dalam bentuk video. Pada pengamatan ketiga yang dilakukan pada pembelajaran hari Selasa tanggal 26 Januari 2021 peneliti melihat guru memberikan tugas kepada siswa untuk menggambar salah satu poster tentang menjaga lingkungan yang ada di buku tematik kelas 4 tema 6 halaman 118 dan menggambar hewan atau tumbuhan yang ada di buku tematik kelas 4 tema 6 halaman 123 di kertas karton yang telah dipotong menjadi 4 bagian dan diwarnai. Selain itu, peneliti juga melihat guru menginstruksikan siswa untuk membuat kolase dengan pertunjuk alat, bahan dan langkah-langkah yang ada di buku tematik kelas 4 tema 6 halaman 123. Pada pengamatan keempat yang dilakukan pada pembelajaran hari Selasa tanggal 2 Februari 2021 di akhir pembelajaran, peneliti melihat guru menginstruksikan siswa untuk mengerjakan soal di buku LKS halaman 23-26 sampai B. Dari sini peneliti menyimpulkan bahwa ketika melakukan kegiatan penutup pembelajaran menggunakan Google Meet, guru memberikan tugas lanjutan di luar pembelajaran.

\section{3) Guru membaca doa sebelum mengakhiri pembelajaran}

Peneliti melakukan kegiatan pengamatan mengenai kegiatan penutup yang berkaitan dengan guru membaca doa sebelum mengakhiri pembelajaran. Berdasarkan hasil pengamatan pertama pada pembelajaran hari Selasa tanggal 12 Januari 2021, pengamatan kedua pada pembelajaran hari Selasa tanggal 19 Januari 2021, pengamatan ketiga pada pembelajaran hari Selasa tanggal 26 Januari 2021, dan pengamatan keempat pada pembelajaran hari Selasa tanggal 2 Februari 2021 peneliti melihat guru membaca surah AlAsr bersama siswa untuk mengakhiri 
pembelajaran. Dari sini peneliti menyimpulkan bahwa ketika melakukan kegiatan penutup pembelajaran menggunakan Google Meet, guru membaca doa sebelum mengakhiri pembelajaran.

\section{4) Guru mengucapkan salam untuk menutup pembelajaran}

Peneliti melakukan kegiatan pengamatan mengenai kegiatan penutup yang berkaitan dengan guru mengucapkan salam untuk menutup pembelajaran. Berdasarkan hasil pengamatan pertama pada pembelajaran hari Selasa tanggal 12 Januari 2021, pengamatan kedua pada pembelajaran hari Selasa tanggal 19 Januari 2021, pengamatan ketiga pada pembelajaran hari Selasa tanggal 26 Januari 2021, dan pengamatan keempat pada pembelajaran hari Selasa tanggal 2 Februari 2021 peneliti melihat guru mengucapkan salam untuk menutup pembelajaran. Dari sini peneliti menyimpulkan bahwa ketika melakukan kegiatan penutup pembelajaran menggunakan Google Meet, guru mengucapkan salam untuk menutup pembelajaran.

Pada kegiatan pendahuluan, guru melakukan beberapa kegiatan pendahuluan. Kegiatan pendahuluan yang dilakukan guru diantaranya adalah membaca doa sebelum belajar sebelum memulai pembelajaran, menanyakan kesiapan siswa, dan melakukan apersepsi atau menghubungkan pengetahuan/pengalaman siswa dengan materi yang akan dipelajari. Kegiatan pendahuluan yang telah disebutkan sesuai dengan Lampiran Permendikbud Nomor 22 Tahun 2016 tentang Standar Proses Pendidikan Dasar dan Menengah BAB IV tentang Pelaksanaan Pembelajaran Bagian B Pelaksanaan Pembelajaran Nomor 1 butir a dan c yang berbunyi, "menyiapkan peserta didik secara psikis dan fisik untuk mengikuti proses pembelajaran dan mengajukan pertanyaanpertanyaan yang mengaitkan pengetahuan sebelumnya dengan materi yang akan dipelajari." $\begin{array}{cccc}\text { Pada } & \text { kegiatan } & \text { inti, guru } \\ \text { menyampaikan } & \text { materi } & \text { pembelajaran, } \\ \text { menggunakan } & \text { bahasa } & \text { yang } & \text { baku, }\end{array}$ menggunakan sumber belajar berupa buku tematik dan buku lembar kerja siswa, dan guru melakukan tanya jawab bersama siswa. Kegiatan pendahuluan dan inti pembelajaran yang dilakukan guru di atas sudah sesuai dengan Pedoman Pelaksanaan Belajar dari Rumah Selama Darurat Bencana Covid-19 di Indonesia Surat Edaran Sekretaris Jendral No. 15 Tahun 2020 Peran Pendidik halaman 7 yang berbunyi, "memastikan persiapan untuk peserta didik, menjelaskan materi yang diajarkan, dan memfasilitasi tanya jawab."

Pada kegiatan penutup guru melakukan tindak lanjut dengan memberikan soal/tugas lanjutan kepada siswa untuk dikerjakan di luar pembelajaran, membaca surah Al-Asr untuk mengakhiri pembelajaran, dan mengucapkan salam untuk menutup pembelajaran. Kegiatan penutup yang telah disebutkan sesuai dengan Lampiran Permendikbud Nomor 22 Tahun 2016 tentang Standar Proses Pendidikan Dasar dan Menengah BAB IV tentang Pelaksanaan Pembelajaran Bagian B Pelaksanaan Pembelajaran Nomor 3 butir c yang berbunyi, "melakukan kegiatan tindak lanjut dalam bentuk pemberian tugas, baik tugas individual maupun kelompok."

Berdasarkan hasil dokumentasi, guru membuat grup kelas WhatsApp untuk berkomunikasi dengan orang tua siswa dan siswa serta memberikan soal/tugas kepada siswa. Hal ini juga sejalan dengan Pedoman Pelaksanaan Belajar dari Rumah Selama Darurat Bencana Covid-19 di Indonesia Surat Edaran Sekretaris Jendral No. 15 Tahun 2020 Peran Pendidik halaman 7 yang berbunyi, "membuat mekanisme untuk berkomunikasi dengan orang tua/wali dan peserta didik dan bila tanpa tatap muka, guru mesti berkordinasi dengan orang tua/wali untuk penugasan belajar." 
3. Penilaian Pembelajaran pada Masa Pandemi di Kelas 4-C SDN Bencongan VI

Setelah melakukan pembelajaran, biasanya guru melakukan penilaian ke siswa. Penilaian yang dilakukan adalah penilaian proses dan hasil pembelajaran. Penilaian juga dibagi menjadi tiga aspek diantaranya aspek sikap, aspek pengetahuan, dan aspek keterampilan. Penilaian proses dilakukan untuk melihat sikap siswa selama proses pembelajaran, sedangkan penilaian pengetahuan dan keterampilan dilakukan untuk mengukur pengetahuan siswa dan keterampilan siswa. Hal inilah yang mendasari pertanyaan bagaimana penilaian pembelajaran pada masa pandemi di sekolah dasar.

Peneliti melakukan wawancara untuk mendapatkan informasi mengenai penilaian pembelajaran pada masa pandemi di sekolah dasar. Wawancara dilakukan untuk menggali informasi guru sebagai pengajar di sekolah. Berikut ini adalah hasil wawancara yang dilakukan oleh peneliti dengan guru mengenai penilaian pembelajaran pada masa pandemi di kelas 4-C SDN Bencongan VI.

\section{a. Penilaian Sikap (Religius \& Sosial)}

Guru menilai sikap siswa melalui Google Meet. Penilaian yang dilakukan yaitu penilaian kerajinan, keaktifan, dan semangat ketika pembelajaran melalui Google Meet. Guru mengetahui cara untuk menyusun perangkat pembelajaran, salah satunya adalah penilaian sikap siswa melalui Kelompok Kerja Guru (KKG) Kecamatan. guru juga melakukan pembiasaan kepada siswa seperti membaca doa sebelum membuka dan menutup pembelajaran. Kendala yang dialami ketika melakukan penilaian sikap siswa pada saat pembelajaran jarak jauh adalah tingkah laku siswa tidak seperti pembelajaran tatap muka, misalnya ketika pembelajaran jarak jauh ada siswa yang tiduran. Selama pembelajaran jarak jauh daring yang hampir setiap hari siswa mengikuti pembelajaran melalui WhatsApp. Pada pembelajaran jarak jauh daring melalui Google Meet, hanya 60\%-70\% siswa yang aktif menjawab pertanyaan guru dan membantu jika ada temannya yang belum tahu/mengerti tentang sesuatu. Selain itu, ada juga siswa yang tidak mengikuti pembelajaran jarak jauh daring dikarenakan tidak memiliki ponsel. Siswa yang tidak memiliki ponsel tersebut juga biasanya tidak mengumpulkan tugas tepat waktu dikarenakan kekurangan informasi mengenai tugas. Guru memberikan solusi terkait hal tersebut dengan menginstruksikan siswa yang tidak memiliki ponsel untuk bergabung dengan siswa yang memiliki ponsel. Terakhir, guru menginstruksikan siswa/orang tua siswa untuk mengisi daftar kehadiran melelui Google Form.

\section{b. Penilaian Pengetahuan}

Perbedaan yang dirasakan guru ketika melakukan penilaian pengetahuan siswa pada pembelajaran tatap muka dengan pembelajaran jarak jauh adalah medianya. Jika pada pembelajaran tatap muka, penilaian dilakukan di buku/kertas, maka pada pembelajaran jarak jauh penilaian dilakukan di Google Form. Guru memilih melakukan penilaian pengetahuan menggunakan Google Form karena efisien. Biasanya soal yang diberikan berbentuk pilihan ganda, guru tidak membuat bentuk soal selain pilihan ganda dikarenakan jika satu angka/huruf dari jawaban siswa tidak sesuai dengan kunci jawaban di Google Form maka akan terdeteksi salah. Terkadang guru membuat soal sendiri dan terkadang mengambil soal dari buku LKS. Biasanya guru melakukan penilaian pengetahuan siswa setiap habis satu subtema/selesai memberikan materi/pembelajaran berupa tes, ujian tengah semester dilakukan setiap tiga bulan sekali, dan ujian akhir semester dilakukan setiap enam bulan sekali. Soal ujian tengah semester dan ujian akhir semester disusun oleh guru kelas 4 (4-A, 4-B, dan 4-C), sedangkan soal ualngan harian disusun oleh guru menggunakan buku paket maupun buku LKS. Siswa biasanya mengerjakan soal peniaian pengetahuan (ulangan harian, UTS, dan UAS) didampingi oleh orang tua siswa.

\section{c. Penilaian Keterampilan}


$\begin{array}{ccc} & \text { Perbedaan yang dirasakan guru ketika } \\ \text { menilai } & \text { keterampilan siswa ketika }\end{array}$ pembelajaran tatap muka dengan pembelajaran jarak jauh daring adalah jika pembelajaran tatap muka penilaian keterampilan siswa dilakukan secara langsung atau membuat produk yang langsung dinilai di tempat (sekolah), sedangkan penilaian keterampilan siswa ketika pembelajaran jarak jauh daring siswa melakukan praktik atau membuat suatu produk di rumah dengan mengikuti video tutorial yang dikirim guru dan dibantu oleh orang tua siswa kemudian dikumpulkan secara personal ke guru dalam bentuk video atau kalau berupa produk dikumpulkan langsung ke sekolah. Penilaian keterampilan siswa yang dilakukan bermacam-macam tergantung materinya, misalnya materi IPA yang mempelajari tentang listrik statis, penilaian keterampilan yang dilakukan adalah dengan menginstruksikan siswa untuk menggosokkan penggaris ke rambut, ada juga penilaian praktik seperti mencangkok, bernyanyi, bercerita, dan olahraga (jalan, lari, menendang bola, dan berenang). Selain itu juga ada penilaian produk seperti membuat pot bunga dari kemasan plastik bekas air mineral, kolase, mozaik dan montase. Guru menggunakan jenis penilaian keterampilan ini karena menurutnya lebih tepat dan lebih mudah. Ketika menilai keterampilan siswa, guru biasanya memberikan nilai 80 bagi siswa yang mengumpulkan video.

Berdasarkan hasil wawancara, dalam menilai sikap (spiritual dan sosial) siswa, guru melakukannya dengan mengamati sikap siswa selama pembelajaran melalui Google Meet. Guru mengamati sikap spiritual siswa seperti ketika siswa membaca doa sebelum memulai dan sebelum mengakhiri pembelajaran. Hal ini juga terlihat ketika peneliti melakukan pengamatan, terlihat siswa sudah terbiasa untuk membaca doa sebelum memulai dan sebelum mengakhiri pembelajaran. Selain sikap spiritual, guru juga menilai sikap sosial siswa ketika pembelajaran melaui Google Meet. Sikap sosial diantaranya seperti siswa memberitahu/membantu temannya yang kesulitan, siswa berpartisipasi dalam tanya jawab, dan kerajinan dalam mengikuti pembelajaran (disiplin).

Berdasarkan hasil dokumentasi, penilaian sikap yang telah disebutkan di atas juga terdapat dalam hasil dokumentasi berupa bagian penilaian sikap di RPP. Kegiatan yang guru lakukan seperti yang sudah dijabarkan di atas sesuai dengan yang termaktub dalam Permendikbud Nomor 23 Tahun 2016 tentang Standar Penilaian Pendidikan Pasal 3 Ayat 2 yang berbunyi, "Penilaian sikap sebagaimana dimaksud pada ayat (1) huruf a merupakan kegiatan yang dilakukan oleh pendidik untuk memperoleh informasi deskriptif mengenai perilaku peserta didik."

Berdasarkan hasil wawancara, penilaian pengetahuan yang dilakukan guru ketika pembelajaran jarak jauh daring melalui Google Form. Tes tulis yang diberikan guru kepada siswa berupa soal pilihan ganda. Guru membuat soal tersebut sendiri dan juga mengambil soal dari buku LKS. Penilaian pengetahuan dilakukan ketika selesai memberikan materi/pembelajaran atau persubtema, ulangan tengah semester dilakukan tiga bulan sekali, dan ulangan akhir semester dilakukan enam bulan sekali. Hal ini sesuai dengan Lampiran Permendikbud Nomor 22 Tahun 2016 tentang Standar Proses Pendidikan Dasar dan Menengah halaman 13 yang berbunyi, "Evaluasi hasil pembelajaran dilakukan saat proses pembelajaran dan di akhir satuan pelajaran dengan menggunakan metode dan alat: tes lisan/perbuatan, dan tes tulis."

Sejalan dengan hasil dokumentasi, guru terlihat memberikan pranala Google Form ulangan harian, ulangan tengah semester/penilaian tengah semester, dan ulangan akhir semester/penilaian akhir semester di grup WhatsApp kelas untuk mengetahui sejauh mana penguasaan pengetahuan siswa. Penilaian pengetahuan yang dilakukan guru seperti yang dijabarkan di atas sesuai dengan Permendikbud Nomor 23 
Tahun 2016 tentang Standar Penilaian Pendidikan Pasal 3 Ayat 3 yang berbunyi, "Penilaian pengetahuan sebagaimana dimaksud pada ayat (1) huruf b merupakan kegiatan yang dilakukan untuk mengukur penguasaan pengetahuan peserta didik."

Berdasarkan hasil wawancara, penilaian keterampilan yang dilakukan guru yakni penilaian produk dan praktik. Penilaian produk dan praktik diberikan tergantung materi. Penilaian produk dan praktik diawali dengan memberikan video tutorial atau menginstruksikan siswa untuk melihat tutorialnya di sumber belajar (buku paket atau LKS). Setelah itu, siswa mengerjakan di rumah didampingi oleh orang tua, setelah selesai, siswa atau orang tua siswa mengumpulkan produk langsung ke sekolah atau mengirimkan video praktik ke guru secara personal.

Sesuai dengan hasil dokumentasi, peneliti melihat di grup WhatsApp kelas, guru mengirimkan video tentang praktik atau produk dan siswa diinstruksikan untuk melakukan atau membuat produk yang sama dengan yang ada di video tersebut. Selain itu, ada video praktik siswa melakukan percobaan yang dikirim guru sebagai contoh untuk siswa lain yang belum melakukan tugas praktik. Penilaian keterampilan menggunakan penilaian praktik dan produk yang dilakukan guru sesuai dengan Permendikbud No 23 Tahun 2016 tentang Standar Penilaian Pendidikan BAB VI Mekanisme Penilaian Pasal 9 Ayat 1 butir d yang berbunyi, "Penilaian keterampilan dilakukan melalui praktik, produk, proyek, portofolio, dan/atau teknik lain sesuai dengan kompetensi yang dinilai."

\section{SIMPULAN DAN REKOMENDASI}

Berdasarkan hasil pembahasan yang telah diuraikan sebelumnya tentang Pembelajaran Jarak Jauh pada Masa Pandemi di Kelas 4-C SDN Bencongan VI meliputi perencanaan pembelajaran pada masa pandemi yang disiapkan guru kelas, pelaksanaan pembelajaran pada masa pandemi yang dilakukan guru kelas, dan penilaian pembelajaran pada masa pandemi yang dilakukan guru kelas. Maka dapat ditarik kesimpulan sebagai berikut:

Guru sudah menyiapkan perencanaan pembelajaran sebelum melakukan pembelajaran pada masa pandemi di kelas 4-C. Berikut ini adalah hal yang dilakukan guru sebelum melakukan pembelajaran di antaranya seperti menyiapkan RPP dengan mengunduhnya dari internet, menyiapkan media pembelajaran berupa video yang didapat dengan mengunduhnya dari internet, menyiapkan sumber belajar berupa buku paket dan buku Lembar Kerja Siswa (LKS), menyiapkan penilaian pengetahuan menggunakan Google Form, menyiapkan tindak lanjut berupa soal, tugas praktik dan produk.

Dalam melaksanaan pembelajaran pada masa pandemi di kelas 4-C, guru tidak melakukan pembelajaran sesuai dengan RPP. Pada kegiatan pendahuluan, guru melakukan kegiatan seperti membaca doa sebelum belajar sebelum memulai pembelajaran, menanyakan kesiapan siswa, dan melakukan apersepsi atau menghubungkan pengetahuan/pengalaman siswa dengan materi yang akan dipelajari. Lalu pada kegiatan inti, guru menyampaikan materi pembelajaran, menggunakan bahasa yang baku, menggunakan sumber belajar berupa buku tematik dan buku lembar kerja siswa, dan guru melakukan tanya jawab bersama siswa. Terakhir, pada kegiatan penutup guru melakukan tindak lanjut dengan memberikan soal/tugas lanjutan kepada siswa untuk dikerjakan di luar pembelajaran, membaca surah Al-Asr untuk mengakhiri pembelajaran, dan mengucapkan salam untuk menutup pembelajaran.

Dalam melakukan penilaian siswa secara daring, peneliti memfokuskan berdasarkan beberapa aspek, yaitu aspek sikap (spiritual dan sosial), aspek pengetahuan, dan aspek keterampilan. Penilaian sikap spiritual dan sosial siswa dilakukan ketika pembelajaran menggunakan Google Meet. Pada penilaian aspek sikap spiritual, guru melakukan 
pembiasaan membaca doa sebelum memulai dan sebelum mengakhiri pembelajaran kepada siswa, sedangkan pada penilaian sikap sosial siswa, guru melakukan penilaian siswa seperti siswa memberitahu/membantu temannya yang kesulitan, siswa berpartisipasi dalam tanya jawab, dan kerajinan dalam mengikuti pembelajaran (disiplin). Pada penilaian aspek pengetahuan, guru memberikan tes tulis berupa soal pilihan ganda melalui Google Form. Terakhir, dalam penilaian keterampilan, guru memberikan tugas berupa penilaian produk dan penilaian praktik.

Berdasarkan simpulan yang telah diuraikan di atas, peneliti memiliki beberapa rekomendasi sebagai bahan referensi atau tambahan kepada pihak terkait mengenai pembelajaran pada masa pandemi di sekolah dasar. Berikut ini adalah beberapa rekomendasinya:

Untuk menambah pengalaman guru, diharapkan ke depannya guru melakukan kegiatan perencanaan yang lebih matang lagi seperti menyusun Rencana Pelaksanaan Pembelajaran (RPP). Pada kegiatan pendahuluan, diharapkan kedepannya guru mengucapkan salam, memberikan motivasi ke siswa, menjelaskan tujuan pembelajaran atau kompetensi dasar, dan menyampaikan jangkauan materi dan penjelasan uraian kegiatan. Terakhir pada kegiatan penutup, diharapkan kedepannya guru menyimpulkan pembelajaran bersama siswa, memberikan umpan balik pembelajaran kepada siswa, dan menginformasikan rencana kegiatan pembelajaran untuk pembelajaran selanjutnya kepada siswa.

Rekomendasi bagi orang tua siswa ketika dilaksanakan pembelajaran pada masa pandemi adalah sisihkan waktunya untuk mendampingi siswa/anaknya ketika pembelajaran atau pengerjaan soal/tugas. Terakhir, jangan mengerjakan soal/ulangan anaknya berkali-kali di Google Form karena akan membingungkan guru untuk menilai.

Peneliti menyadari masih banyak keterbatasan dalam penelitian ini, oleh karena itu, peneliti harap kedepannya peneliti lain dapat melakukan penelitian sejenis dan menggunakan jangkauan wilayah yang lebih luas, dilakukan di jenajng pendidikan lain, dan menggunakan lebih banyak sampel agar penelitian menjadi jauh lebih kaya.

\section{DAFTAR PUSTAKA}

Analisis Data COVID-19 Indonesia (Update Per 15 November 2020). Tersedia di https://drive.google.com/uc?export=do wnload\&id=1 AUtxKNY5XW4S6-

2PzfKnflL6kru11Mv5 diakses pada tanggal 29 September 13.00 WIB

Arsendy, S., dkk. (2020). Teaching and Learning During School Closure: Lessons from Indonesia. Tersedia di https://thinkasia.org/bitstream/handle/11540/12448 /ISEAS_Perspective_2020_89.pdf?seq uence $=1$ diakses pada tanggal 25 September 2020 pukul 17.00 WIB

LAMPIRAN PERATURAN MENTRI PENDIDIKAN DAN KEBUDAYAAN NOMOR 22 TAHUN 2016 TENTANG STANDAR PROSES PENDIDIKAN DAN MENENGAH Tersedia di http://repositori.kemdikbud.go.id/4790 /2/Permendikbud_Tahun2016_Nomor 022_Lampiran.pdf diakses tanggal 15 Juni 2021 pukul 17.58 WIB

Organisation for Economic Co-operation and Development (OECD). (2020). EDUCATION RESPONSES TO COVID-19: IMPLEMENTING A WAY FORWARD. Tersedia di http://www.oecd.org/officialdocument s/publicdisplaydocumentpdf/?cote $=\mathrm{ED}$ $\mathrm{U} / \mathrm{WKP}(2020) 12 \&$ docLanguage $=\mathrm{En}$ diakses pada tanggal 29 November 2020 pukul 13.05 WIB

PERATURAN MENTRI PENDIDIKAN DAN KEBUDAYAAN REPUBLIK INDONESIA NOMOR 23 TAHUN 2016 TENTANG STANDAR PENILAIAN PENDIDIKAN Tersedia 
di https://bsnp-indonesia.org/wpcontent/uploads/2009/09/Permendikbu d_Tahun2016_Nomor023.pdf diakses tanggal 15 Juni 2021 pukul 17.56 WIB

Satgas Penanganan COVID-19. (2020). Peta Sebaran. Tersedia https://covid19.go.id/peta-sebaran diakses pada tanggal 24 November 2020 pukul 17.00 WIB 